\title{
Proses Personal Selling dalam Pemasaran KPR BCA
}

\author{
Rofian Dedi Susanto
}

Institut Ilmu Sosial dan Manajemen STIAMI

Program Studi Manajemen Komunikasi - Fakultas Ilmu Sosial dan Ilmu Manajemen

Email: rofiandedi@gmail.com

\section{ARTICLE INFO ABSTRACT}

Keywords: personal selling personal selling stages satisfaction score
The mortgage is one of the excellent facilities from BCA. As a top product, BCA is aggressively offering that facility to its customers. BCA KCU Thamrin offered mortgages through their marketing officer. This study aims to examine and analyze the implementation of a personal selling strategy by BCA KCU Thamrin's marketing officers to achieve the target. This research is descriptive qualitative research with a case study method and the data collection technique uses in-depth interviews. The data analysis is using data reduction, data presentation, and making conclusions. The validity of the data is checked by the source triangulation method. The result of this research shows that the marketing officers of BCA KCU Thamrin strategy for offering mortgages to their customers is by integrating and follow the stages of personal selling strategy, which are Prospecting and Qualifying, Pre approach, Approach, Presentation and Demonstration, Overcoming Objection, Closing the Sale, and Follow Up. The implementation of personal selling strategy viciously has delivered BCA KCU Thamrin to achieve the best of satisfaction score by customers in 49 from 50 (98\%). The conclusion that can be drawn is that achieving the best satisfaction score at BCA KCU Thamrin shows the strength of personal selling strategy.

\section{PENDAHULUAN}

KPR atau Kredit Pemilikan Rumah adalah salah satu produk unggulan di dunia perbankan. Bahkan ada bank yang memilih fokus bisnisnya adalah penjualan produk KPR. Bank Central Asia (BCA) sebagai salah satu bank terkemuka di Indonesia juga memilih untuk ikut ambil bagian dalam meramaikan promosi produk KPR. Perlu diketahui bahwa sebagian masyarakat Indonesia, mampu memenuhi kebutuhan pokok berupa tempat tinggal menggunakan fasilitas perbankan yang disebut KPR tersebut. Dengan begitu banyaknya pilihan fasilitas KPR yang ditawarkan oleh perbankan Indonesia termasuk BCA, tentu membutuhkan strategi komunikasi pemasaran yang tepat.

Para marketing officer sebagai garda terdepan dalam penjualan fasilitas KPR diberikan target khusus untuk memenuhi ekspektasi perusahaan terhadap penyerapan dana pihak ketiga dalam bentuk fasilitas KPR yang diberikan kepada masyarakat. Hal ini membutuhkan effort yang lebih dari para marketing officer untuk mencapai target yang telah ditentukan oleh manajemen perusahaan.

Bank merupakan salah satu institusi yang berbentuk lembaga jasa keuangan sehingga produk yang dijual sebagian besar berbentuk jasa. Produk yang dijual biasanya berupa simpanan (tabungan, giro \& deposito), pinjaman (kredit tempat tinggal, kendaraan, tempat usaha, modal kerja \& multi guna), penyimpanan barang (safe deposit box), kiriman uang, jual beli valas, dan sebagainya.

Proses pengenalan produk perbankan, termasuk KPR kepada masyarakat dilakukan melalui suatu kegiatan yang disebut komunikasi pemasaran. Komunikasi pemasaran adalah upaya untuk menjadikan seluruh kegiatan pemasaran dan promosi perusahaan dapat menghasilkan citra atau image yang bersifat konsisten bagi konsumen. Komunikasi pemasaran menuntut agar setiap pesan yang keluar harus berasal dari sumber yang sama sehingga segala informasi yang diumumkan perusahaan memiliki kesamaan tema serta positioning yang sama di mata konsumen (Morissan, 2010: 9).

Personal selling merupakan salah satu strategi komunikasi pemasaran yang lazim dilakukan di dunia perbankan. Kegiatan ini dilakukan melalui tenaga pemasaran (marketing officer) yang ditempatkan di masing-masing cabang. Adanya persaingan dalam memenangkan hati nasabah diantara 
perusahaan perbankan di Indonesia menjadi motivasi bagi BCA untuk terus memberikan pelayanan terbaiknya sesuai dengan tagline BCA, yaitu Senantiasa di Sisi Anda (nasabah) dengan layanan yang lebih baik. Untuk itu, BCA selalu melakukan program pelatihan bagi para marketing officer agar dapat memenuhi kebutuhan dan bahkan melebihi ekspektasi nasabah.

BCA saat ini telah memiliki ribuan cabang yang tersebar di seluruh Indonesia. Dari sekian banyak cabang yang sudah berdiri, BCA KCU (Kantor Cabang Utama) Thamrin memiliki keunikan tersendiri karena lokasinya berada di gedung yang sama dengan Kantor Pusat BCA di Menara BCA, kawasan Thamrin, Bundaran Hotel Indonesia (HI), Jakarta Pusat. KCU Thamrin telah berdiri sejak tanggal 25 November 2008 dan hingga saat ini terus menunjukkan eksistensinya.

Untuk memenuhi kebutuhan nasabah, tentunya pihak bank, dalam hal ini BCA KCU Thamrin memiliki kepentingan dalam mengembangkan strategi personal selling untuk memperoleh bisnis dari nasabah sehingga dapat mencapai target "Solusi BCA" yang diberikan oleh pihak manajemen, dimana salah satunya adalah Solusi untuk kepemilikan rumah melalui fasilitas KPR. Untuk itu, para marketing officer harus memahami dan menguasai setiap tahapan dalam proses menjalankan strategi personal selling.

Permasalahan yang menjadi fokus dari penelitian ini adalah bagaimana tahapan pelaksanaan strategi personal selling yang digunakan oleh para marketing officer BCA KCU Thamrin sebagai salah satu strategi komunikasi pemasaran yang dilakukan dalam memasarkan fasilitas KPR kepada nasabah.

Tujuan dari penelitian ini adalah untuk menjawab pertanyaan pada fokus penelitian, yaitu untuk mengkaji dan menganalisis tahapan pelaksanaan strategi personal selling yang dilakukan oleh para marketing officer BCA KCU Thamrin untuk memasarkan fasilitas KPR kepada seluruh nasabah, khususnya "nasabah fokus" dari BCA KCU Thamrin.

\section{KERANGKA TEORITIS}

\section{Strategi Komunikasi Pemasaran}

Strategi dalam komunikasi dimaknai sebagai suatu cara untuk mengatur pelaksanaan operasi komunikasi agar berhasil. Strategi komunikasi pada hakikatnya adalah perencanaan (planning) dan manajemen (management) untuk mencapai satu tujuan. Untuk mencapai tujuan tersebut, strategi tidak berfungsi sebagai peta jalan yang hanya menunjukkan arah, tetapi juga harus menunjukkan taktik operasionalnya (Abidin, 2015: 155). Effendy (2011: 10) mengartikan strategi komunikasi sebagai suatu perencanaan yang efektif dalam penyampaian pesan sehingga mudah dipahami oleh komunikan dan bisa menerima apa yang telah disampaikan sehingga bisa mengubah sikap atau perilaku seseorang.

Morissan (2010: 5) memaknai komunikasi pemasaran sebagai suatu aktivitas pemasaran yang berusaha menciptakan kesadaran atau pengetahuan mengenai produk dengan berbagai atributnya, menginformasikan kelebihan produk, menciptakan citra produk, atau menciptakan sikap positif, preferensi, dan keinginan membeli produk yang dikomunikasikan. Jannah dan Moefad (2019: 128) menyatakan bahwa strategi komunikasi pemasaran dapat dilakukan dengan menerapkan strategi harga, pemanfaatan media promosi, kerjasama komunitas, serta bersinergi dengan pemerintah dan stakeholder lain yang terkait. Jadi, penelitian ini akan membahas mengenai strategi komunikasi pemasaran yang dilakukan oleh para marketing officer sehingga akan menjelaskan mengenai tahapan aktivitas pemasaran yang dilakukan untuk menciptakan kesadaran atau pengetahuan mengenai produk, menginformasikan kelebihan produk, dan memunculkan keinginan untuk membeli produk yang dikomunikasikan.

\section{Strategi Personal Selling}

Kusniadji (2016: 91) menyatakan bahwa personal selling adalah wujud komunikasi yang berhadapan dengan konsumen secara tatap muka dan improvisasi dari penjualan dengan menggunakan komunikasi person to person. Tidak seperti iklan, personal selling melibatkan kontak langsung antara penjual dan pembeli, baik secara tatap muka ataupun melalui alat telekomunikasi. Dalam hal ini, penjual dapat langsung memodifikasi informasi yang harus disampaikan setelah menerima tanggapan dari calon pembeli (Morissan, 2010: 34).

Risa, Prihatin, dan Fitrianur (2017: 267) menyampaikan bahwa strategi personal selling yang tepat di dunia perbankan hendaknya melakukan profesionalisme penjualan, negosiasi, dan hubungan 
pemasaran. Sedangkan Shintia, Mantala, dan Irfan (2018: 141) menyebutkan bahwa pelaksanaan strategi personal selling perbankan meliputi kegiatan referral (rujukan dari nasabah existing), territorial management (serbu pasar di kawasan sekitar bank), dan internal data mining (pengolahan data internal bank). Di lain pihak, Kusniadji (2016: 91-92) menyatakan bahwa proses personal selling sebagai salah satu aktivitas komunikasi pemasaran melalui beberapa tahapan, yaitu pertama, perhatian (attention). Pada tahap ini, tujuan komunikasi pemasaran dari marketing officer adalah menempatkan konsumen sasaran mereka pada tahap penerimaan. Kedua, minat (interest). Pada tahap ini, tujuan personal selling adalah menarik perhatian dari konsumen sasaran sehingga konsumen dapat memiliki minat yang kuat pada produk yang ditawarkan.

Ketiga, keinginan (desire). Pada tahap ini, para marketing officer harus memiliki kemampuan untuk menjawab setiap pertanyaan dari pelanggan dan hal ini penting untuk meyakinkan konsumen agar merasa yakin atas reputasi produk yang ditawarkan perusahaan dan produk yang dibeli konsumen merupakan pilihan yang tepat di mata pelanggan. Keempat, tindakan (action). Setelah para marketing officer mampu menciptakan suasana komunikasi pemasaran yang dapat menimbulkan kepercayaan dan keyakinan konsumen, maka kemungkinan besar konsumen akan memesan dan membeli produk yang ditawarkan.

\section{Komunikasi Persuasif}

Kata persuasi berasal dari bahasa latin yaitu persuasio. Sedangkan kata kerja yang terbentuk adalah persuadere yang berarti membujuk, mengajak, atau merayu. Sehingga komunikasi persuasif dimaknai oleh Putri (2016: 4) sebagai suatu proses komunikasi yang bertujuan untuk mengubah sikap, pendapat, atau perilaku seseorang untuk mencapai tujuan dan sasaran tertentu yang dilakukan secara halus, luwes, mengandung sifat-sifat manusiawi dengan dilakukan perancanaan yang matang.

Adapun tujuan dari proses komunikasi persuasif menurut De Vito dalam Riyanto dan Mahfud (2012: 51) ada dua, yaitu 1) mengubah atau menguatkan keyakinan (believe) dan sikap (attitude) audiens, dan 2) mendorong audiens melakukan sesuatu atau memiliki tingkah laku (behaviour) tertentu yang diharapkan.

Komunikasi persuasif sering digunakan atau dimanfaatkan dalam kegiatan komunikasi pemasaran. Hal ini karena di dalam praktiknya, kegiatan pemasaran tidak hanya memerlukan produk yang bagus, penetapan harga yang sesuai, tatanan dan tampilan (display) yang menarik, tetapi juga memerlukan kemampuan komunikasi persuasif dari tenaga penjualan atau marketing officer (Machfoedz, 2010: 16). Selain itu, seorang marketing officer harus mampu memahami perilaku konsumennya. Perilaku konsumen sangat kompleks dan sulit diprediksi karena konsumen akan bersikap rasional dalam setiap keputusan pembelian mereka.

\section{Kerangka Pemikiran}

Penelitian ini bertujuan untuk mengkaji dan menganalisis secara detail tentang pelaksanaan strategi personal selling oleh para marketing officer BCA KCU Thamrin. Secara terpola, dapat dilihat pada Gambar 1 di bawah ini.

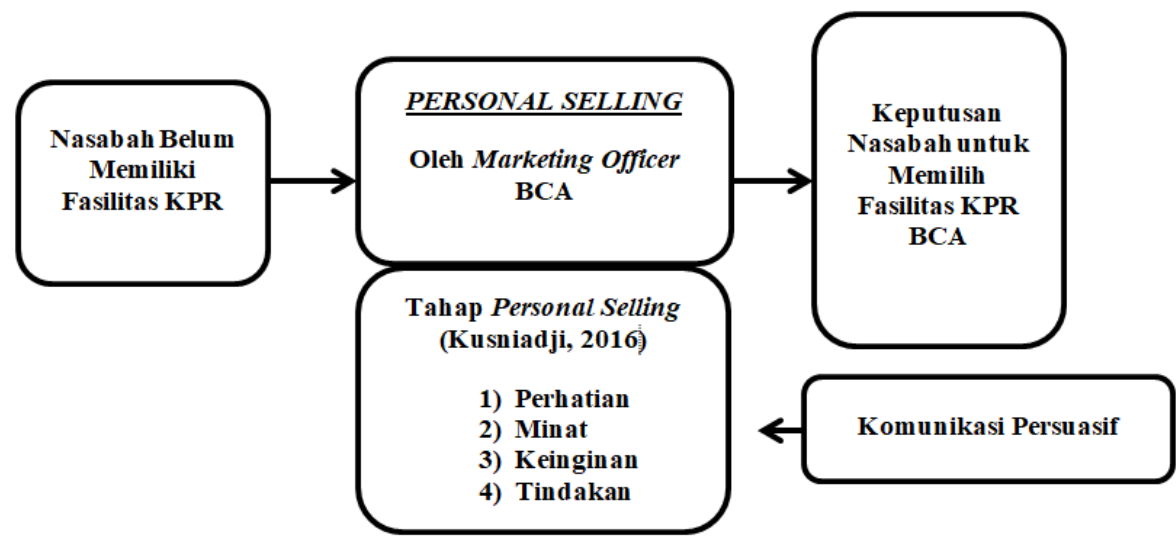

Gambar 1. Kerangka Pemikiran Penelitian 


\section{METODE PENELITIAN}

Penelitian ini menggunakan pendekatan kualitatif dengan paradigma konstruktivisme. Hal ini karena peneliti ingin mengkonstruksikan tentang pelaksanaan strategi personal selling yang dilakukan oleh para marketing officer dalam memasarkan fasilitas KPR kepada para nasabah BCA KCU Thamrin. Penelitian ini menggunakan paradigma konstruktivisme karena dilakukan secara aktif dan berkesinambungan dalam memperoleh data dan informasi dari proses wawancara mendalam dan datadata sekunder mengenai strategi personal selling yang dilakukan oleh para marketing officer di lokasi penelitian sehingga lahir pemahaman sendiri yang dikonstruksikan oleh peneliti hingga akhirnya diolah menjadi hasil penelitian.

Penelitian ini didesain sebagai penelitian studi kasus mengenai proses pelaksanaan strategi personal selling yang spesifik dan khusus dilakukan oleh para marketing officer BCA KCU Thamrin dalam memasarkan fasilitas KPR dengan berusaha menemukan makna, menyelidiki proses, serta memperoleh pengertian dan pemahaman yang mendasari proses tersebut. Kasus yang diangkat adalah mengenai tingkat kepemilikan fasilitas KPR yang relatif rendah oleh nasabah BCA, khususnya oleh "nasabah fokus" BCA KCU Thamrin. Strategi personal selling yang dijalankan oleh para marketing officer digunakan untuk meningkatkan kepemilikan fasilitas KPR oleh para nasabah tersebut.

Penelitian ini dilakukan di BCA KCU Thamrin yang berlokasi di Menara BCA, Jl. M. H. Thamrin No. 1 Jakarta Pusat, karena merupakan satu-satunya kantor cabang yang berlokasi satu gedung dengan Kantor Pusat sehingga memiliki akses informasi mengenai produk-produk (solusi) perbankan yang sangat mudah dari cabang ke pusat, terutama fasilitas KPR. Penelitian ini akan difokuskan pada marketing officer, yaitu account officer (AO) dan relationship officer (RO), karena account officer (AO) dan relationship officer (RO) adalah tonggak utama cabang dalam melakukan penjualan program solusi perbankan. Penelitian ini dilaksanakan pada tanggal 1 Juli 2020 sampai dengan 30 Agustus 2020.

Key informan dalam penelitian ini terdiri dari 3 (tiga) orang yang memenuhi seluruh kriteria di atas, yaitu seorang KPBC, seorang Head AO, dan seorang Head RO. Hasil dari wawancara dengan key informan akan diolah dan dianalisis untuk memperoleh data dan informasi terkait penelitian yang dilakukan. Data dan informasi tersebut akan ditampilkan pada bab selanjutnya, yaitu terkait hasil penelitian dan pembahasan. Teknik analisis data dilakukan melalui tiga (3) tahap, yaitu data reduction (reduksi data), data display (penyajian data), dan Conclusion Drawing/Verification.

\section{HASIL PENELITIAN DAN DISKUSI}

\section{Gambaran Umum Objek Penelitian}

Penelitian ini difokuskan pada tahapan strategi personal selling yang dilakukan oleh para marketing officer BCA KCU Thamrin, khususnya yang dilakukan oleh para account officer dan relationship officer. Penelitian tidak dilakukan pada Staf Pengembangan Bisnis Cabang (SPBC) karena mereka tidak berhubungan langsung dalam proses marketing. Mereka hanya melakukan pengadministrasian dan melakukan pemrosesan fasilitas kredit yang diajukan oleh nasabah melalui para marketing officer.

Account officer (AO) adalah marketing officer yang memegang portofolio nasabah yang didominasi oleh para debitur di BCA. Debitur adalah nasabah yang memiliki fasilitas kredit modal kerja (KMK) atau Kredit Investasi (KI) di BCA. Selain debitur, AO juga memegang beberapa "nasabah fokus non debitur". Sedangkan relationship officer (RO) memegang portofolio "nasabah fokus non debitur" selain yang dipegang oleh AO. Nasabah yang di-handle oleh RO biasanya lebih banyak daripada AO karena AO memiliki tanggung jawab dalam melakukan mantain nasabah debitur berupa perpanjangan fasilitas kredit setiap tahun, tambahan dan/atau pengurangan fasilitas kredit, dan juga nasabah-nasabah lain yang terkait dengan debitur.

Selain nasabah fokus, AO dan RO juga melayani nasabah walk in customer, baik referensi dari $\mathrm{KCU}, \mathrm{KCP}$, maupun dari nasabah existing yang selama ini sudah di-handle.

\section{Hasil Penelitian}

Para marketing officer dituntut untuk mampu melakukan komunikasi yang persuasif dalam setiap personal selling yang dilakukan agar mampu mengarahkan nasabah dan meyakinkan nasabah 
untuk memilih solusi perbankan berupa KPR di BCA dibandingkan dari bank lain. Dalam hal ini, tidak diperkenankan memberikan informasi yang salah atau menyesatkan, karena hal itu dapat menimbulkan kekecewaan dan dapat menghancurkan reputasi perusahaan di mata para nasabah. Personal selling yang dilakukan oleh para marketing officer di BCA KCU Thamrin dianalisis menggunakan tahap-tahap personal selling yang disampaikan oleh Kusniadji (2016: 91-92) berikut ini:

\section{Tahap Perhatian (Attention)}

Sebelum Tahap Perhatian dijalankan, biasanya dilakukan pemilihan prospek konsumen terlebih dahulu. Namun, setiap cabang BCA di seluruh Indonesia tidak terlalu dipusingkan dalam hal melakukan pemilihan prospek nasabah. Hal ini karena setiap cabang sudah memiliki detail data nasabah yang belum memiliki solusi KPR untuk diprospek oleh masing-masing kantor cabang, termasuk BCA KCU Thamrin yang telah ditentukan oleh pihak Kantor Pusat dan disebut sebagai "Nasabah K1" dengan kriteria termasuk nasabah Prioritas dan Solitaire BCA, nasabah-nasabah yang banyak melakukan transaksi di cabang-cabang tertentu, nasabah yang memiliki prospek besar untuk ditambahkan kepemilikan "Solusi BCA"-nya.

Pemilihan "Nasabah K1" yang dilakukan oleh Kantor Pusat memiliki dampak positif bagi cabang. Dampak positif yang hadir adalah masing-masing cabang tidak perlu menghabiskan banyak waktu untuk melakukan pemilihan nasabah, karena semua sudah ditentukan oleh Kantor Pusat. Masing-masing cabang harus menerima "Nasabah K1" yang diberikan dan harus mengelolanya sebaik mungkin.

Keadaan ini bukan berarti bahwa marketing officer tidak melalui proses memilih dan menilai prospek. Masing-masing marketing officer harus memilih dan menilai prospek dari masing-masing "Nasabah K1" atau yang disebut juga "Nasabah Fokus" BCA KCU Thamrin tersebut. Sortir dapat dilakukan dengan memilih nasabah yang belum memiliki fasilitas KPR BCA. Setelah proses sortir selesai dilakukan, maka para marketing officer dapat melakukan kegiatan-kegiatan marketing pada tahapan-tahapan personal seling selanjutnya. Selain nasabah-nasabah yang diperoleh dari Kantor Pusat, para marketing officer BCA juga dapat memanfaatkan networking yang dimilikinya untuk mencari calon debitur KPR tersebut.

Tahap perhatian (attention) dimulai dengan pendekatan yang dilakukan dengan cara menghubungi setiap nasabah yang prospek, baik secara tatap muka maupun melalui media komunikasi. Hubungan pertama biasanya dilakukan melalui telepon, sms, atau wa. Hubungan pertama adalah kegiatan perkenalan diri para marketing officer kepada para nasabah. Hubungan pertama ini memiliki peran yang sangat penting dalam proses personal selling oleh para marketing officer. Jika hubungan pertama ini berhasil, maka nasabah akan terbuka dan mau untuk dihubungi oleh para marketing officer. Tetapi jika nasabah menunjukkan sikap tertutup dan tidak berkenan untuk dihubungi, maka akan sulit untuk membentuk engagement dengan nasabah tersebut.

Hal itu tentunya tidak perlu dirisaukan oleh para marketing officer karena jumlah nasabah yang terbuka pasti akan lebih banyak dibandingkan nasabah yang tertutup. Sehingga AO dan RO selaku marketing officer dapat lebih intensif membangun customer relationship dengan nasabah yang terbuka sehingga kesempatan untuk meningkatkan nilai solution index atau penggunaan "Solusi BCA" oleh nasabah semakin besar.

Melalui proses pendekatan, marketing officer dapat mengetahui tentang karakter nasabah, kesukaan atau hobi nasabah, serta kebutuhan-kebutuhan perbankan nasabah. Setelah mengetahui kebutuhan nasabah, maka marketing officer dapat melanjutkan pada aktivitas selanjutnya, yaitu presentasi mengenai "Solusi BCA" yang akan ditawarkan ke nasabah terkait kebutuhan nasabah tersebut pada tahap minat (interest).

\section{Tahap Minat (Interest)}

Tahap Minat akan tercipta dengan memulai proses presentasi mengenai produk yang ditawarkan. Dalam proses ini, product knowledge dan kemampuan berkomunikasi persuasif merupakan hal sangat penting. Marketing officer harus dapat menjelaskan mengenai produk KPR yang sesuai dengan kebutuhan nasabah. Mulai dari jenis KPR, penjelasan tentang syarat dan ketentuan KPR, manfaat dan tata cara mendapatkan fasilitas tersebut. Hal ini menunjukkan pentingnya 
penguasaan terhadap product knowledge dari semua jenis fasilitas KPR yang akan ditawarkan kepada nasabah.

Kemampuan para marketing officer dalam menjalankan komunikasi persuasif dapat dilihat dari bagaimana marketing officer mampu merangkai kata dalam rangka menyampaikan pesan komunikasi persuasifnya. Berikut ini adalah beberapa contoh komunikasi persuasif yang disampaikan oleh para marketing officer BCA KCU Thamrin pada tahap Presentasi dan Demonstrasi di saat menawarkan fasilitas KPR BCA :

"Bu, sudah tahu belum kalau BCA mau ada event baru? Namanya BCA OnlinEXPO Bu. Di sana aka nada promo menarik dari fasilitas BCA, termasuk KPR. Bunganya miring banget Bu."

"Pak, BCA sekarang lagi ada promo KPR dengan suku bunga super murah lho. Cuma 5,88\% p.a. Pak. Gimana?"

"Pak, kalau mau beli rumah pakai KPR BCA saja Pak. Saya jamin, suku bunga kita jauh lebih murah dibandingin bank lain. Mau saya buatkan simulasinya Pak?"

Kalimat-kalimat diatas merupakan contoh yang disampaikan oleh para key informan terkait langkah awal para marketing officer dalam proses presentasi untuk menarik minat dari nasabah. Kalimat di atas bukanlah suatu kalimat baku yang wajib disampaikan ke nasabah pada tahap ini, karena semua disesuaikan dengan karakter nasabah, kebutuhan nasabah, serta kenyamanan marketing officer dalam berinteraksi dengan nasabah. Tetapi kalimat-kalimat tersebut dapat dijadikan acuan dalam membangun komunikasi dengan nasabah dalam memasarkan produk KPR ke masing-masing nasabah yang di-handle oleh para marketing officer.

\section{Tahap Keinginan (Desire)}

Tahap Keinginan dimulai ketika nasabah sudah mulai menunjukkan keinginannya untuk memiliki suatu produk yang ditawarkan dengan disertai beberapa tambahan yang lebih dari sekedar minat. Misalnya adalah munculnya keberatan mengenai suatu hal terkait produk tersebut. Pada dasarnya, sudah menjadi hal yang biasa apabila nasabah merasa keberatan dengan "solusi" yang ditawarkan. Tugas marketing officer adalah menangkap keberatan tersebut, menguraikan masalah yang dihadapi serta mencari solusi dari masalah tersebut. Oleh sebab itu, product knowledge memiliki tingkat kepentingan yang tinggi untuk dikuasai oleh setiap marketing officer. Dengan pengetahuan yang menyeluruh, para $\mathrm{AO}$ dan $\mathrm{RO}$ mampu mengatasi keberatan nasabah dengan menjelaskan kelebihan-kelebihan yang dimiliki "Solusi BCA" dibandingkan produk lain yang mungkin diperbandingkan oleh nasabah. Selain itu, kemampuan komunikasi persuasif para marketing officer juga diperlukan pada tahap ini agar mampu mengarahkan nasabah pada tahap selanjutnya, yaitu Tahap Closing the Sale.

Berbicara mengenai rayuan dalam mengatasi keberatan dari nasabah, berikut adalah contoh kata-kata persuasif yang biasa disampaikan oleh para marketing officer BCA KCU Thamrin disesuaikan dengan keberatan yang muncul:

$\mathrm{N}$ : "Pak, saya sih tertarik ya sama suku bunga KPR BCA. Murah sih, tapi itu lho, kenapa harus ada penaltinya sih kalau dilunasi dipercepat? Saya kan kalau ada uang lebih pengennya saya lunasin sebagian. Kan lumayan untuk ngurangin pokok dan nurunin angsuran bulannya"

M : "Oh Ibu ada rencana untuk pelunasan sebagian ya? Tenang Bu, kita ada kok solusinya. KPR BCA kan fleksibel Bu."

$\mathrm{N}$ : "Lho ada solusinya? Apa tuh Pak?"

M : "Kalau memang Ibu ada rencana pelunasan sebagian pas ada uang lebih, sebaiknya Ibu ambil KPR-nya yang fixed 2 tahun saja. Itu dilunasi kapan saja bebas penalti. Bahkan baru jalan 4 bulan, terus ada uang lebih dan mau lunas sebagian, boleh Bu. Benar-benar bebas penalti."

N : "Wah bagus kalau gitu. Tapi Pak, nanti kalau sudah lewat 2 tahun kena suku bunga floating dong."

M : "Iya Bu. Tapi tenang saja Bu. Suku bunga floating BCA kan terbilang rendah. Cuma 11,5\% p.a. untuk saat ini. Kalau bank lain bisa sampai 13 atau bahkan $14 \%$ lho Bu. Dan, 
yang lebih menariknya lagi, kalau sudah masuk suku bunga floating, Ibu bisa kok minta migrasi ke suku bunga fixed yang lagi promo saat itu nantinya."

$\mathrm{N}$ : "Menarik banget itu Pak. Ah.... yang bener nih Pak? Nanti susah lagi kalau mau proses pelunasan dipercepat sama migrasi suku bunganya."

M : "Oh tentu tidak Bu. Pasti gampang urusnya. Ibu tinggal kontak ke saya kalau mau pelunasan dipercepat ataupun migrasi suku bunga. Selain itu, Ibu juga bisa melalui Halo BCA di 1500888."

Berdasarkan pernyataan-pernyataan diatas, maka dapat disimpulkan bahwa dalam menghadapi keberatan dari nasabah, para marketing officer lebih menitikberatkan pada kelebihan-kelebihan produk sehingga nasabah merasa yakin bahwa meskipun ada keberatan-keberatan yang muncul, tetapi itu merupakan penawaran solusi yang terbaik dan menguntungkan bagi nasabah jika dibandingkan produk-produk solusi lain yang ada di pasaran. Kemampuan komunikasi persuasif para marketing officer diuji kembali pada tahap ini. Jika tingkat pemahaman terkait product knowledge dan kemampuan dalam mempersuasi nasabahnya tinggi, maka para marketing officer akan mampu membujuk nasabah untuk closing fasilitas KPR.

\section{Tahap Tindakan (Action)}

Setelah nasabah menerima penjelasan AO atau RO yang mempresentasikan "solusi" yang dibutuhkan, dalam hal ini fasilitas KPR, maka marketing officer tersebut dapat segera masuk dalam Tahap Tindakan, yaitu mengumpulkan dokumen-dokumen yang dibutuhkan untuk closing "solusi" tersebut. Jika dokumen sudah lengkap, maka proses pengajuan fasilitas KPR BCA tersebut dapat segera direalisasikan. Proses Closing the Sale (penjualan) ini ditandai dengan penyerahan dokumendokumen persyaratan untuk pengajuan fasilitas KPR BCA oleh nasabah kepada marketing officer BCA.

Ketelatenan para marketing officer pada saat berkomunikasi dengan nasabah dalam rangka memasarkan "Solusi BCA" ditunjukkan dengan kesabaran mereka dalam menjawab setiap pertanyaan nasabah terkait "Solusi BCA" yang ditawarkan. Ketelatenan tersebut dapat dilihat pada tahap Minat dan Keinginan, yaitu tepatnya dalam proses presentasi dan mengatasi keberatan dari nasabah.

Tindak lanjut (follow up) dalam proses closing fasilitas KPR BCA oleh marketing officer merupakan langkah lanjutan dalam Tahap Tindakan. Dalam menindaklanjuti proses tersebut, marketing officer harus memastikan bahwa nasabah sudah mendapatkan "solusi" yang dibutuhkan, nasabah merasa puas, dan dapat memenuhi ekspektasi nasabah.

Tingkat kepuasan nasabah BCA KCU Thamrin yang tinggi terlihat dari hasil survei yang menunjukkan bahwa kepuasan nasabah terhadap layanan kredit BCA KCU Thamrin sebesar 49 dari nilai maksimal 50. Berikut adalah hasil rekapitulasi survei tersebut.

Tabel 1. Tingkat Kepuasan Nasabah KPR BCA KCU Thamrin

\begin{tabular}{lrrrr}
\hline \multirow{2}{*}{ Nasabah } & \multicolumn{4}{c}{ Tingkat Kepuasan } \\
\cline { 2 - 5 } & Pengajuan & Analisa & \multicolumn{1}{c}{ Akad } & Rata-Rata \\
\hline HPO & 50 & 50 & 50 & 50 \\
IWA & 50 & 50 & 45 & 48,33 \\
OSO & 50 & 50 & 50 & 50 \\
FMA & 50 & 45 & 45 & 46,67 \\
YHU & 50 & 50 & 50 & 50 \\
& & & TOTAL & 49 \\
\hline
\end{tabular}

Setelah nasabah mendapatkan "Solusi BCA" yang dibutuhkan, yakni KPR dan menyatakan kepuasannya, maka tugas marketing officer untuk membina customer engagement (CE) menjadi lebih mudah. CE dapat dibina melalui proses komunikasi yang intensif, baik secara langsung (tatap muka) ataupun tidak langsung (melalui media komunikasi). Dengan intensifnya proses komunikasi di saat proses pengajuan fasilitas KPR BCA, maka nasabah dan marketing officer menjadi lebih mengenal satu sama lain. Setelah saling kenal, maka marketing officer akan lebih mudah dalam menghubungi nasabah, tidak hanya terkait masalah produk dan layanan BCA, tetapi juga dapat membahas hal-hal lain yang sifatnya lebih ringan, seperti hobi, pekerjaan, kegiatan sehari-hari dan sebagainya. Dari 
sinilah customer engagement menjadi lebih kuat terbina. Tahapan personal selling yang dilakukan oleh marketing officer BCA pada keseluruhan prosesnya dapat dilihat pada tabel berikut ini.

Tabel 2. Tahapan Personal Selling oleh Marketing Officer BCA KCU Thamrin

\begin{tabular}{ll} 
Tahapan Personal Selling & \multicolumn{1}{c}{ Aktivitas Marketing Officer } \\
\multirow{3}{*}{ Perhatian (Attention) } & Pemilihan \& Penilaian Prospek Konsumen/Nasabah \\
& Penelusuran \& Pengumpulan Data Nasabah \\
Minat (Interest) & Pendekatan kepada Nasabah \\
Keinginan (Desire) & Presentasi Produk/Solusi kepada Nasabah \\
& Mengatasi Keberatan dari Nasabah \\
Tindakan (Action) & Closing Penjualan \\
& Follow Up terkait Penjualan \\
& Membina Customer Enggagement
\end{tabular}

\section{Diskusi}

Berdasarkan penelitian yang dilakukan, pelaksanaan strategi personal selling di BCA KCU Thamrin dalam memasarkan produk KPR telah menggunakan tahapan strategi personal selling menurut Kusniadji (2016: 91-92) yaitu Tahap Perhatian (Attention), Tahap Minat (Interest), Tahap Keinginan (Desire), dan Tahap Tindakan (Action). Pada masing-masing tahapan, marketing officer BCA melakukan beberapa tindakan, yaitu:

\section{Tahap Perhatian (Attention)}

Tindakan yang dilakukan pada tahap perhatian adalah pemilihan \& penilaian prospek nasabah, penelusuran \& pengumpulan data nasabah, serta pendekatan kepada nasabah. Pemilihan \& penilaian penilaian prospek nasabah adalaah tindakan yang dilakukan untuk memilih dan menilai siapa saja nasabah yang memiliki prospek untuk ditawarkan fasilitas KPR BCA. Jika prospek nasabah sudah terpilih, maka tindakan selanjutnya adalah melakukan penelusuran \& pengumpulan data nasabah agar marketing officer mengetahui tentang profil nasabah yang dipilih. Tindakan selanjutnya adalah pendekatan kepada nasabah tersebut, yang bisa dilakukan dengan cara berkomunikasi, baik komunikasi tatap muka ataupun menggunakan media komunikasi, seperti telepon, sms, chat, dan email. Semua tindakan yang dilakukan adalah bertujuan untuk mendapatkan perhatian dari nasabah.

\section{Tahap Minat (Interest)}

Setelah mendapatkan perhatian dari nasabah, strategi personal selling dapat memasuki tahap ke dua, yaitu Tahap Minat. Kegiatan yang dilakukan adalah presentasi produk yang ditawarkan, dalam hal ini fasilitas KPR BCA kepada nasabah. Tujuan dari kegiatan presentasi ini adalah untuk mendapatkan minat dari nasabah terhadap produk KPR BCA.

\section{Tahap Keinginan (Desire)}

Pada Tahap Keinginan, nasabah sudah mulai menunjukkan keinginannya terhadap produk yang ditawarkan dengan disertai beberapa tambahan yang lebih dari sekedar minat. Misalnya adalah munculnya keberatan mengenai suatu hal terkait produk tersebut. Maka tindakan yang dilakukan oleh marketing officer adalah mengatasi keberatan nasabah. Aktivitas tersebut lebih menitikberatkan pada kelebihan-kelebihan produk sehingga nasabah merasa yakin bahwa meskipun ada keberatan-keberatan yang muncul, tetapi produk yang ditawarkan tersebut adalah yang terbaik jika dibandingkan dengan produk-produk lain yang ada di pasaran.

\section{Tahap Tindakan (Action)}

Aktivitas pada Tahap Tindakan adalah aktivitas-aktivitas yang merupakan akhir dari proses marketing atau penjualan, tetapi tetap dilakukan maintain nasabah agar ke depannya, nasabah bisa melakukan pembelian produk atau solusi kembali, pembelian produk lain, ataupun memberikan referensi nasabah lain kepada marketing officer. Aktivitas-aktivitas tersebut adalah closing penjualan, follow up terkait penjualan, serta membina customer engagement dengan nasabah agar relationship selalu terjaga.

Strategi personal selling dalam pemasaran fasilitas KPR BCA juga telah sesuai dengan strategi personal selling yang tepat di dunia perbankan sebagaimana yang telah disampaikan oleh 
Risa, Prihatin, dan Fitrianur (2017: 267) yaitu melakukan profesionalisme penjualan, negosiasi, dan hubungan pemasaran. Profesionalisme penjualan dilakukan oleh para marketing officer BCA KCU Thamrin dengan menguasai product knowledge terkait produk KPR BCA. Negosiasi dilakukan pada saat menyampaikan kelebihan-kelebihan fasilitas KPR BCA dan kemampuan bernegosiasi dengan nasabah pada aktivitas mengatasi keberatan nasabah pada Tahap Keinginan. Hubungan pemasaran dilakukan dengan cara membina customer engagement pada Tahap Tindakan untuk menjaga relationship dengan nasabah, meningkatkan loyalitas nasabah, serta menciptakan closing lain secara berkelanjutan.

Marketing officer BCA KCU Thamrin juga menjalankan tiga strategi personal selling perbankan menurut Shintia, Mantala, dan Irfan (2018: 141). Kegiatan referral atau pemberian referensi calon nasabah oleh nasabah existing BCA, territorial management atau canvassing (melakukan identifikasi, pengelompokan, dan pemilihan calon nasabah di kawasan sekitar cabang), serta internal data mining atau pengolahan data internal yang dimiliki oleh bank terkait nasabahnasabah potensial sangat dimanfaatkan dengan baik untuk pemasaran seluruh produk atau solusi perbankan yang ada di BCA, termasuk KPR BCA.

\section{SIMPULAN}

Pelaksanaan strategi personal selling produk KPR di BCA KCU Thamrin dilakukan sesuai tahap-tahap personal selling menurut Kusniadji yaitu tahap perhatian (attention), tahap minat (interest), tahap keinginan (desire), dan tahap tindakan (action). Peneliti menemukan adanya aktivitasaktivitas yang dilakukan pada setiap tahapan, yaitu pemilihan \& penilaian prospek nasabah, penelusuran \& pengumpulan data nasabah, dan pendekatan kepada nasabah pada Tahap Perhatian, presentasi produk pada Tahap Minat, mengatasi keberatan pada Tahap Keinginan, serta closing penjualan, follow up, dan membina customer engagement pada Tahap Tindakan.

Dalam pelaksanaan strategi personal selling, para marketing officer menggunakan strategi tersebut secara tatap muka dan melalui media komunikasi. Dalam pelaksanaan strategi tersebut, terungkap fakta bahwa tingkat penguasaan terhadap product knowledge dan kemampuan para marketing officer dalam berkomunikasi secara persuasif terhadap nasabah sangat menentukan keberhasilan proses personal selling dalam memasarkan fasilitas KPR BCA. Tingkat kepuasan nasabah BCA KCU Thamrin yang tinggi berdasarkan hasil survei menunjukkan penggunaan strategi personal selling selain memudahkan para marketing officer dalam menawarkan fasilitas perbankan, juga memudahkan nasabah untuk memahami fasilitas yang ditawarkan sehingga puas dengan fasilitas atau produk yang diberikan.

Rekomendasi yang dapat diberikan adalah penggunaan strategi personal selling dapat dilakukan untuk oleh perusahaan yang bergerak di bidang perbankan untuk produk atau fasilitas selain KPR. Tahapan strategi personal selling harus dilaksanakan secara fokus dan terarah tanpa mengurangi setiap tahapan yang ada. Analolisis mengenai tahapan personal selling juga dapat dilakukan untuk kegiatan penelitian di luar produk perbankan, baik produk-produk yang berwujud seperti produk kecantikan, perawatan tubuh, fashion, perlengkapan rumah, dan sebagainya maupun produk-produk tidak berwujud seperti jasa travel, jasa arsitektur, jasa appraisal, jasa manajemen investasi, dan sebagainya.

\section{DAFTAR PUSTAKA}

[1\} Abidin, Y. Z. 2015. Manajemen Komunikasi (Filosofi, Konsep, dan Aplikasi). Bandung: Pustaka Setia.

[2] Bungin, B. 2011. Penelitian Kualitatif, Komunikasi, Ekonomi, Kebijakan Publik, dan Ilmu Sosial Lainnya. Jakarta: Kencana Prenadamedia Grup.

[3] Creswell, J. W., 2014. Research Design: Qualitative, Quantitative, and Mixed Methods Approaches: The fourth edition. Thousand Oaks, CA: Sage Publications

[4] Effendy, O. U., 2011. Ilmu Komunikasi: Teori dan Prakteknya. Bandung: Remaja Rosdakarya. 
[5] Jannah, U. dan A. M. Moefad. 2019. Strategi Komunikasi Pemasaran Wisata Baru Setigi di Gresik Jawa Timur. Jurnal Ilmu Komunikasi. Vol. 9 (2): 114-129.

[6] Kusniadji, S. 2016. Strategi Komunikasi Pemasaran dalam Kegiatan Pemasaran Produk Consumer Goods (Studi Kasus pada PT Expand Berlian Mulia di Semarang). Jurnal Komunikasi. Vol. 8 (1): 83-98.

[7] Machfoedz, M. 2010. Komunikasi Pemasaran. Yogyakarta: Cakra Ilmu.

[8] Moleong, L. J. 2010. Metode Penelitian Kualitatif. Bandung: Remaja Rosda Karya.

[9] Morissan, M. A. 2010. Periklanan: Komunikasi Pemasaran Terpadu. Jakarta: Kencana Prenadamedia Grup.

[10] Putri, P. K. 2016. Aplikasi Pendekatan-Pendekatan Persuasifpada Riset Komunikasi Pemasaran: Iklan Melibatkan penciptaan dan Penerimaan Pesan Komunikasi Persuasif Mengubah Perilaku Pembelian. Jurnal The Messenger. Vol. VIII (1): 1-16.

[11] Risa, M.; E. S. Prihatin; dan Fitrianur. 2017. Strategi Personal Selling untuk Meningkatkan Volume Penempatan Mesin EDC pada PT. Bank Negara Indonesia (Persero) Tbk. Unit CNM Banjarmasin. Prosiding Seminar Nasional ASBIS 2017 Politeknik Negeri Banjarmasin. Vol. 2 (1): 254-268.

[12] Riyanto, W. F. \& Mahfud, M. 2012. Komunikasi Islam I (Perspektif Integrasi-Interkoneksi). Yogyakarta: Gauh Patria.

[13] Shintia, N.; R. Mantala; dan M. Irfan. 2018. Strategi Promosi Personal Selling dalam Mencapai Target Produk Kredit Komersial pada PT. Bank Pembangunan Daerah Jawa Barat dan banten, Tbk. Cabang Banjarmasin. At-Tadbir: Jurnal Ilmiah Manajemen. Vol. 2 (2): 130-142.

[14] Sugiyono. 2013. Metode Penelitian Kuantitatif, Kualitatif, dan $R \&$ D. Bandung: Alfabeta. 